\title{
Mustafakemalpaşa Çayı'nın (Bursa) Su Kalitesinin Faktör Analizi Kullanılarak Değerlendirilmesi
}

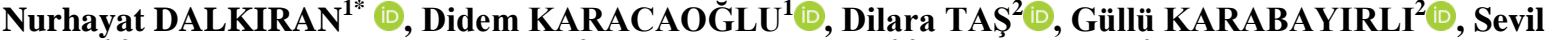

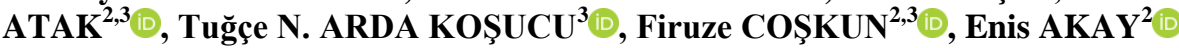

\author{
${ }^{1}$ Bursa Uludağ Üniversitesi Fen-Edebiyat Fakültesi, Biyoloji Bölümü, Bursa, Türkiye \\ ${ }^{2}$ Bursa Uludağ Üniversitesi Fen Bilimleri Enstitüsü Biyoloji A.B.D. Bursa, Türkiye \\ ${ }^{3}$ BUSKİ Havza Koruma Dairesi Başkanlığı, İçme Suyu Laboratuvarı Bursa, Türkiye
}

*Sorumlu Yazar: dalkiran@uludag.edu.tr

Geliş 26 Ağustos 2019; Kabul 28 Kasım 2019; Basım 01 Mart 2020.

\begin{abstract}
Alıntılama: Dalkıran, N., Karacaoğlu, D., Taş, D., Karabayırlı, G., Atak, S., Arda Koşucu, T.N., Coşkun, F., \& Akay, E. (2020). Mustafakemalpaşa Çayı'nın (Bursa) su kalitesinin faktör analizi kullanılarak değerlendirilmesi. Acta Aquatica Turcica, 16(1), 124-137. https://doi.org/10.22392/actaquatr.610888
\end{abstract}

\section{Özet}

Bu çalışmada Mustafakemalpaşa Çayı'nda belirlenen iki örnekleme noktasından Ekim 2016 - Eylül 2017 tarihleri arasında aylık olarak alınan su örneklerinde bazı fizikokimyasal ve ağır metal analizi sonuçları akarsuyun su kalitesini belirlemek için değerlendirilmiştir. Veri setine Ana Bileşenler Analizi/Açıklayıcı Faktör Analizi uygulanmış ve toplam varyansın \% 76,426'sını açıklayan üç faktör yükü belirlenmiştir. Faktör I'de bikarbonat, bor, arsenik, antimon, sodyum ve kalsiyumun kuvvetli pozitif faktör yükü oluşturduğu ve toplam varyansın \% 28,76'sını açıkladığı tespit edilmiștir. Faktör II toplam varyansın \% 25,999'unu açıklamış, bu faktörde alüminyum, demir ve toplam azot kuvvetli negatif, magnezyum ve sülfat ise pozitif faktör yükü oluşturmuştur. Faktör III’te çözünmüş oksijen negatif, florür, fosfat fosforu ve silis ise pozitif faktör yükü oluşturmuştur. Bu faktör toplam varyansın \% 21,667'sini kapsamıştır. Her üç faktör yükünün havzanın madencilik faaliyetleri ve jeolojik yapısını yansıttığı, daha az oranda ise havzada yapılan tarımsal faaliyetlerin baskı unsuru oluşturduğu belirlenmiştir. Çalışmada ölçülen fizikokimyasal değişkenlerin ve bazı ağır metal analizlerinin yıllık ortalamaları ulusal yönetmeliklerdeki standart değerler ile karşılaştırılmıştır. Mustafakemalpaşa Çayı'nda ölçülen bazı ağır metallerin (bor, arsenik, cıva, krom, nikel, alüminyum ve demir) Yerüstü Su Kalitesi Yönetmeliği'ne göre yıllık ortalama çevresel kalite standardı ve/veya maksimum çevresel kalite standardının üstünde olduğu tespit edilmiştir. Nitrat azotu hariç tüm besin tuzlarının ise II. ya da III. sınıf su kalitesini yansıttığı, toplam fosfor derişimi açısından akarsuyun ötrofik karakterde, toplam azot miktarı açısından ise akarsuyun mezotrofik ila ötrofik karakter arasında olduğu tespit edilmiștir. Mustafakemalpaşa Çayı bulunduğu bölgede tarım arazilerinin sulanması için çok önemli bir su kaynağı olduğu için sulama suyu kriterleri açısından da su kalitesi araştırılmış ve akarsuyun sulama suyu kalitesinin yüksek bor derişimi dışında iyi kalitede olduğu tespit edilmiştir. Ancak Mustafakemalpaşa Çayı'nda tespit edilen yüksek bor derişiminin bora yüksek tolerans gösteren bitkiler için belirlenen sınır değerin iki kat üstünde olduğu belirlenmiştir.

Anahtar kelimeler: Mustafakemalpaşa Çayı, su kalitesi, ağır metaller, sulama suyu, açıklayıcı faktör analizi

Use of Factor Analysis to Evaluate the Water Quality of Mustafakemalpaşa Stream (Bursa)

\section{Abstract}

In this study, to determine the water quality, some physicochemical and heavy metal analysis results of water samples taken from two sampling points in Mustafakemalpaşa Stream among October 2016 - September 2017 were evaluated. Principal Component Analysis/Explanatory Factor Analysis was applied to the data set and three factor loadings, explaining $76.426 \%$ of the total variance were determined. In Factor I, it was determined that bicarbonate, boron, arsenic, antimony, sodium and calcium caused a strong positive factor load and explained $28.76 \%$ of the total variance. Factor II explained $25.999 \%$ of the total variance. In this factor, aluminum, iron and total nitrogen were strongly negative and magnesium and sulfate were positive factor loadings. Dissolved oxygen was negative in factor III, and fluoride, phosphate phosphorus, and silica had a positive factor load. This factor covered $21.667 \%$ of the total variance. It was determined that all three factors reflect the mining activities and geological structure of the basin, and to a lesser extent, agricultural activities in the basin constitute a pressure factor. The annual averages of physicochemical variables and some heavy metal analyzes results which measured in the study were compared with the standard values in national regulations. Some heavy metals (boron, arsenic, mercury, chromium, nickel, aluminum and iron) measured in Mustafakemalpaşa Stream are found to be above the annual average environmental quality standard and / or maximum environmental quality standard according to the Surface Water 
Quality Regulation. It was determined that all nutrients except nitrate nitrogen reflect II. or III. class water quality and the stream is eutrophic in terms of total phosphorus and between a mesotrophic and eutrophic character in terms of total nitrogen concentrations. Since Mustafakemalpaşa stream is an important source of water for irrigating agricultural lands, water quality was also investigated in terms of irrigation water criteria and the water quality of the stream was good quality except for high boron concentration. However, it was found that the high boron concentration detected in Mustafakemalpaşa Stream was two times higher than the limit value for the plants with high tolerance to boron.

Keywords: Mustafakemalpaşa Stream, water quality, heavy metals, irrigation water, explanatory factor analysis

\section{Gİiș}

Canlıların varlığını sürdürebilmesi için en önemli doğal kaynaklardan biri sudur. Günümüzdeki en önemli çevresel problemlerden biri ise su kirliliğidir. Su kaynaklarının kirlenmesi hem su içi canlılarına hem de sudan içme, kullanma ve sulama suyu olarak yararlanan insanlar için büyük sorun teşkil etmektedir. Su kaynaklarının insan ve çevre sağlığının korunması için sürekli izlenmesi ve gerekli koruma tedbirlerinin alınması gerekmektedir. Ülkemizde yapılan çalışmalar yerüstü sularımızın (göl ve akarsular) yaklaşık 1/3'ünün hassas su kütlesi olduğunu göstermiştir (HSKY, 2016).

Günümüzde su kaynaklarının üzerinde oluşan kirlilik ve diğer çevresel baskıları belirlemek için istatistiksel yöntemlerden yararlanılmaktadır. Tek ve iki değişkenli istatistiksel analizler iki değişken arasındaki ilişkiyi açıklayan analizler oldukları için birçok kirleticinin bir arada bulunduğu su kaynaklarında hangi kirletici/kirleticilerin su kaynağı üzerinde bask1 oluşturduğunu çok iyi açıklayamazlar. Çok değişkenli istatistiksel analizler ise çok sayıda değişken arasındaki ilişkileri ve su kalitesi üzerine muhtemel çevresel baskıları açıklayabilen analizlerdir. Bu nedenle su kütleleri üzerindeki muhtemel çevresel baskıları araştırmak için sıklıkla kullanılırlar (Shrestha ve Kazama, 2007; Varol vd., 2012; 2013; Köse vd., 2014; Tokatlı vd., 2014; Şimşek vd., 2017). Bu çok değişkenli analizlerden bir tanesi Açımlayıcı Faktör Analizidir. Faktör analizi çeşitli amaçlar için kullanılan yöntemlerden bir tanesidir. Faktör analizi büyük veri setlerinin yorumlanması, su kalitesinin değerlendirilmesi, değişkenler arasındaki ilişkilerin belirlenmesi gibi çeşitli amaçlar için yaygın olarak kullanılmakta olup, literatürde bu analizin uygulandığı çok sayıda araştırma mevcuttur (Liu vd., 2003; Tokatli vd., 2016).

Mustafakemalpaşa Çayı Orhaneli ve Emet çaylarının birleşmesi ile oluşan Susurluk Havzası içinde kalan çok önemli bir su kaynă̆ımızdır. Geçmiş yıllarda Orhaneli ve Emet çaylarında B, As, Ag kirliliği araştırılmış ve kirlilik kaynakları tartışılmıştır (Arslan ve Çelik, 2015; Tokatlı vd., 2013; 2014; 2016). Ancak Emet ve Orhaneli çaylarının birleşmesi ile oluşan ve ülkemizin 14 RAMSAR alanından biri olan Uluabat Gölü'nü besleyen Mustafakemalpaşa Çayı'nın su kalitesi ve ağır metal içeriği ile ilgili çalışmalar sınırlı sayıdadır (Semiz, 2014; Omwene vd., 2019). Mustafakemalpaşa Çayı Kemalpaşa Ovası'nın sulama suyu ihtiyacının önemli bir bölümünü karşılaması nedeniyle de bölgenin önemli bir su kaynağını oluşturmaktadır. Bu nedenle akarsuyun su kalitesinin belirlenmesi çok önemlidir.

Bu çalışmada Mustafakemalpaşa Çayı'nın su kalitesi üzerinde baskı unsuru oluşturabilecek kirlilik kaynaklarını açımlayıcı faktör analizi (AFA) kullanarak belirlemek ve akarsuyun su kalitesini bazı ulusal yönetmeliklere göre değerlendirmek amaçlanmıştır.

\section{MATERYAL ve YÖNTEM Çalışma Alanı}

Mustafakemalpaşa (Kirmasti) Çayı, Susurluk Havzası'nın bir alt havzası olan Uluabat Gölü Alt Havzası'nda yer alan ve gölü besleyen en önemli kaynaktır. Mustafakemalpaşa Çayı üzerinde membadan mansaba doğru Döllük (M1) ve Ayazköy (M2) olmak üzere iki örnekleme noktas1 belirlenmiştir. Döllük istasyonu Mustafakemalpaşa İlçesi'nin membasında yer alırken, Ayazköy istasyonu ise mansabında bulunmaktadır. Çalışma alanı ve örnekleme noktaları Şekil 1'de gösterilmiş̧ir. 


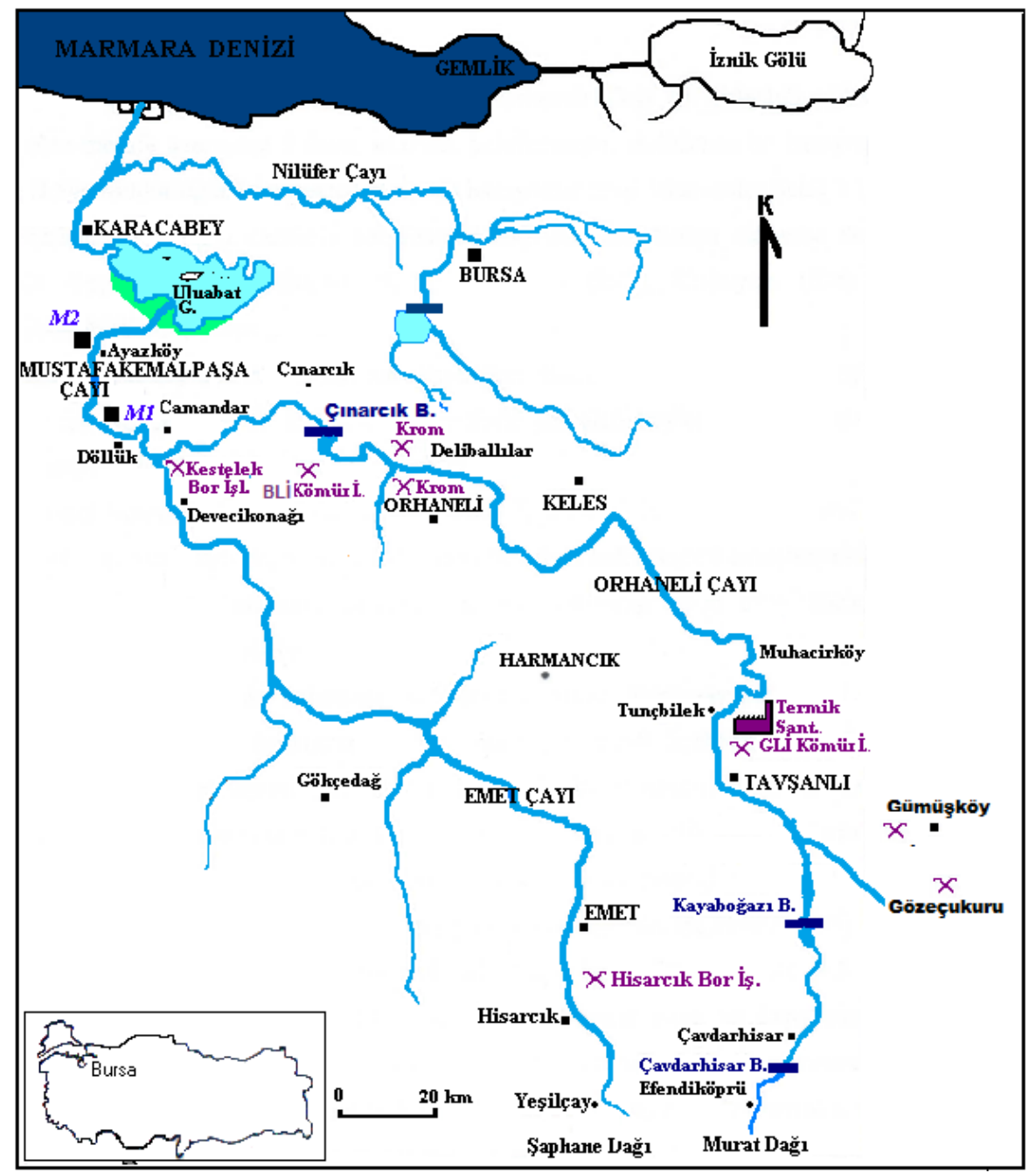

Şekil 1. Uluabat Gölü alt havzası ve örnekleme noktaları

Mustafakemalpaşa Çayı, Orhaneli ve Emet çaylarının Mustafakemalpaşa ilçesi Camandar Köyü mevkiinde birleşmesi ile oluşur ve yaklaşık $43 \mathrm{~km}$ sonra Uluabat Gölü’ne dökülür. Orhaneli Çayı, Kütahya ili Çavdarhisar Beldesi'nde Murat Dağı'nın kuzey yamaçlarından doğmakta ve yaklaşık 276 km akış yolu kat etmektedir. Emet Çayı ise Kütahya ili Gediz ilçesinde Şaphane Dağı'nda 1100 m'de doğmakta ve yaklaşık $180 \mathrm{~km}$ aktıktan sonra Orhaneli Çayı ile birleşmektedir (Anonim, 1982). Her iki çayın da büyük kısmı Kütahya ili sınırları içinden geçmekte ve bu nedenle bu bölgelerde oluşan kirliliği, madencilik faaliyetlerini ve havzanın jeolojik yapısını önemli ölçüde Mustafakemalpaşa Çayı'na taşımaktadırlar. Bu nedenle bu iki çayda oluşan kirlilik doğrudan Mustafakemalpaşa Çayı'na ve akabinde de ülkemizin 14 RAMSAR alanından biri olan Uluabat Gölü'ne yansımaktadır.

Mustafakemalpaşa Çayı'ndan alınan su ile Mustafakemalpaşa Ovası'nda bulunan yaklaşık 165.000 dekar ekim alanına sulama suyu verilmektedir. En çok sulanan ürünler ise 48.867,39 dekar ekim alanı ile mısır, 22.889,39 dekar ekim alanı ile sebzedir (Anonim, 2016). Bunun yaklaşık 15.000 dekarında domates üretilmektedir.

\section{Havzanın jeolojik yapısı}

Mustafakemalpaşa Çayı'nı besleyen iki büyük akarsu olan Orhaneli ve Emet çaylarının havzalarının büyük kısmı Kütahya İli sınırları içinde kalmaktadır. Kütahya ülkemizin en önemli maden kaynaklarının bulunduğu ilimizden biridir. Bu madenlerden bir tanesi bor madenidir. Kütahya Emet'te bulunan borat yatağında Ca-boratlardan kolemanit $\left(\mathrm{Ca}_{2} \mathrm{~B}_{6} \mathrm{O}_{11} .5 \mathrm{H}_{2} \mathrm{O}\right)$ ve meyerhofferit $\left(\mathrm{Ca}_{2} \mathrm{~B}_{6} \mathrm{O}_{11} .7 \mathrm{H}_{2} \mathrm{O}\right)$; $\mathrm{Ca} / \mathrm{Na}$ boratlardan üleksit $\left(\mathrm{NaCaB}_{5} \mathrm{O}_{9} .8 \mathrm{H}_{2} \mathrm{O}\right)$ ve propertit $\left(\mathrm{NaCaB}_{3} \mathrm{O}_{9} .5 \mathrm{H}_{2} \mathrm{O}\right) ; \mathrm{Mg}-$ boratlardan hidroborasit $\left(\mathrm{CaMgB}_{6} \mathrm{O}_{11} \cdot 6 \mathrm{H}_{2} \mathrm{O}\right)$ ve borasit $\left(\mathrm{MgB}_{7} \mathrm{O}_{13} \mathrm{Cl}\right)$; As-boratlardan terrujit $\left(\mathrm{Ca}_{4} \mathrm{MgAs}_{2} \mathrm{~B}_{12} \mathrm{O}_{28} \cdot 2 \mathrm{H}_{2} \mathrm{O}\right)$ ve kahnit $\left(\mathrm{Ca}_{2} \mathrm{BAsO}_{6} \cdot 2 \mathrm{H}_{2} \mathrm{O}\right)$ ve Sr-boratlardan tunellit $\left(\mathrm{SrB}_{6} \mathrm{O}_{10} \cdot 4 \mathrm{H}_{2} \mathrm{O}\right)$ ve 
viçit-A $\left(\mathrm{Sr}_{4} \mathrm{~B}_{22} \mathrm{O}_{37} .7 \mathrm{H}_{2} \mathrm{O}\right)$ bulunmaktadır (Helvac1, 1984; 2003; 2015a, b). Eti Maden Emet Bor İşletme Müdürlügü Hisarcık ve Espey olmak üzere iki açık ocaktan kolemanit cevheri üretimi gerçekleştirmektedir. Bu havzadan çıkarılan kolemanit borik asit tesislerinde işlenerek piyasaya sunulmaktadır. Hisarcık-Espey formasyonu, dünya kolemanit rezervlerinin yaklaşık \% 40'1nı, Türkiye'deki rezervlerinin ise \% 55'ini oluşturmaktadır (Anonim, 2019).

Yapılan çalışmalar Emet borat havzasında bor mineralleri ile birlikte birçok mineralin de bulunduğunu göstermektedir. $\mathrm{Bu}$ mineraller; kalsit $\left(\mathrm{CaCO}_{3}\right)$, dolomit $\left(\mathrm{CaMg}\left(\mathrm{CO}_{3}\right)_{2}\right)$, anhidrit $\left(\mathrm{CaSO}_{4}\right)$, selestit $\left(\mathrm{SrSO}_{4}\right)$, jips $\left(\mathrm{CaSO}_{4} \times 2 \mathrm{H}_{2} \mathrm{O}\right)$, realgar (AsS), orpiment $\left(\mathrm{As}_{2} \mathrm{O}_{3}\right)$ ve doğal kükürttür (Helvac1, 1984; 2003; 2015b). Emet borat havzasında tüf ve tüflü kayaların yapısında da $\mathrm{SiO}_{2}(\%$ 56,93-62,5), $\mathrm{Al}_{2} \mathrm{O}_{3}\left(\%\right.$ 12,55-13,85), $\mathrm{CaO}\left(\%\right.$ 1,55-8,12), $\mathrm{Na}_{2} \mathrm{O}\left(\%\right.$ 0,13-0,3), $\mathrm{MgO}\left(\%\right.$ 1,94-4,97), $\mathrm{K}_{2} \mathrm{O}(\%$ 9,75$10,48), \mathrm{Fe}_{2} \mathrm{O}_{3}(\% 0,12-0,83), \mathrm{FeO}(\% 0,28-1,45), \mathrm{TiO}_{2}(\% 0,06-0,46)$ ve $\mathrm{MnO}(\% 0,03)$ bulunduğu tespit edilmiştir (Helvac1, 2003).

Borat mineralleri dışında Kütahya havzasında feldispat $\left(\mathrm{XAl}_{(1-2)} \mathrm{Si}_{(3-2)} \mathrm{O}_{(8)}\right)$, manyezit $\left(\mathrm{MgCO}_{3}\right)$, florit $\left(\mathrm{CaF}_{2}\right)$, talk $\left(\mathrm{Mg}_{3} \mathrm{Si}_{4} \mathrm{O}_{10}(\mathrm{OH})_{2}\right.$, gümüş, bakır, kurşun, çinko, antimon, demir, mangan, krom madenleri de bulunmaktadır (Oygür ve Erler, 1999; Özgenç, 1993; MTA, 2010a). Bursa-Harmancık'ta bulunan krom madeni ülkemizin en eski krom madenidir (Anonim, 2001). Krom madenciliğinin Emet Çayı su kalitesi üzerinde olumsuz etkileri olduğu belirlenmiştir (Tokatlı vd., 2014).

Emet Havzası'nda bulunan borat minerallerinden dört tanesi günümüzde işletilmeyen ve Orhaneli Çayı kıyısında bulunan ve Bursa - Mustafakemalpaşa sınırları içinde kalan Kestelek maden yatağında da bulunmaktadır. Bu dört borat minerali ise; kolemanit, üleksit, propertit ve hidroborasittir. Kestelek cevher zonu içindeki kaya tipi olan trakiandezik tüf, bor ile birlikte St, Li ve As içermektedir (Helvacı ve Alonso, 2000). Kestelek’te tüf ve tüflü kayaların analizine bakıldığında $\mathrm{SiO}_{2}(\% 55,0), \mathrm{Al}_{2} \mathrm{O}_{3}(\%$ $16,9), \mathrm{CaO}(\% 4,9), \mathrm{Na}_{2} \mathrm{O}(\% 3,57), \mathrm{MgO}(\% 3,23), \mathrm{K}_{2} \mathrm{O}(\% 2,9), \mathrm{Fe}_{2} \mathrm{O}_{3}(\% 2,33), \mathrm{FeO}(\% 0,22), \mathrm{TiO}_{2}$ $(\% 0,54)$ ve $\mathrm{MnO}(\% 0,02)$ içerdikleri tespit edilmiştir (Helvacı vd., 1993). Bu maden yatağının işletildiği dönemlerde Bor madenciliğinin Orhaneli Çayı su kalitesi üzerine önemli etkileri olduğu tespit edilmiştir (Dalkıran, 2006; Semiz, 2014).

Uluabat Gölü Alt Havzası'ndaki en önemli madencilik faaliyetlerinden biri Orhaneli Çayı üzerine önemli etkileri olan, Kütahya-Tavşanlı'da bulunan Garp Linyitleri İşletmesi'dir (GLİ). Ayrıca Tavşanlı'nın $3 \mathrm{~km}$ doğusunda bulunan Gözeçukuru As-Sb-Pb-Zn maden ocağı da aktif olarak işletilmektedir (Arık, 2012; Şener ve Karakuş, 2017). Şener ve Karakuş (2017) As-Sb-Pb-Zn ve kömür madenlerinin Tavşanlı bölgesinin en önemli madencilik aktivitelerinden olduğunu söylemektedirler. Gümüşköy'de bulunan ülkemizin tek Gümüş madeni de aktif olarak işletilmektedir (MTA, 2010a; Arık ve Yaldız, 2010). Aynı zamanda Bursa-Gümüşpınar'da bulunan kömür ocağı da (MTA, 2010b) Türkiye Kömür İşletmeleri Bursa Linyitleri İşletmesi (BLİ) tarafından işletilmektedir. MTA (2010b) verilerine göre Bursa ilinde 10 adet krom ocağı aktif olarak işletilmektedir. Bursa Orhaneli'de 2 ve Mustafakemalpaşa'da 1 krom maden ocağı bulunmaktadır. Bunun yanında olivin $\left((\mathrm{Mg}, \mathrm{Fe})_{2}\left[\mathrm{SiO}_{4}\right]\right)$ maden ocağ 1 ve işleme tesisleri de Mustafakemalpaşa'da bulunmaktadır (MTA, 2010b).

\section{Su Kalitesi Analizleri}

$\mathrm{Bu}$ çalışmada Mustafakemalpaşa Çayı su kalitesini belirlemek için akarsuyun üst ve alt bölümlerini temsil eden iki örnekleme noktasından (Döllük ve Ayazköy) Ekim 2016 - Eylül 2017 tarihleri arasında aylık su örnekleri alınmıştır. Su örnekleri 1 litrelik polietilen şişelerin yüzeyden dibe doğru daldırılması ile standart yöntemler ile alınmıştır. Su sıcaklı̆̆ı, pH, elektriksel iletkenlik (EC) ve çözünmüş oksijen (ÇO) Lovibond marka multiprob ile arazi esnasında yerinde ölçülmüştür. Sodyum $(\mathrm{Na})$, potasyum $(\mathrm{K})$, magnezyum $(\mathrm{Mg})$, kalsiyum $(\mathrm{Ca})$, florür $(\mathrm{F})$, klorür $(\mathrm{Cl})$, nitrit azotu $\left(\mathrm{NO}_{2}-\mathrm{N}\right)$, nitrat azotu $\left(\mathrm{NO}_{3}-\mathrm{N}\right)$, amonyum azotu $\left(\mathrm{NH}_{4}-\mathrm{N}\right)$, sülfat $\left(\mathrm{SO}_{4}\right)$ analizleri TETRA marka İyon Kromatografi cihazında, bor (B), antimon (Sb), arsenik (As), bakır $(\mathrm{Cu})$, cıva $(\mathrm{Hg})$, krom $(\mathrm{Cr})$, kurşun $(\mathrm{Pb})$, nikel $(\mathrm{Ni})$, selenyum $(\mathrm{Se})$, demir $(\mathrm{Fe})$, mangan $(\mathrm{Mn})$, alüminyum $(\mathrm{Al})$ analizleri Perkin Elmer marka ICP-MS cihazında akredite bir laboratuvar olan BUSKİ içme suyu laboratuvarında standart yöntemlere göre (APHA, 1998) gerçekleştirilmiştir. Toplam azot (TN), toplam fosfor (TP), silis ( $\mathrm{Si}$ ), toplam sertlik (TH) ve askıda katı madde (AKM) analizleri ise Bursa Uludağ Üniversitesi Limnoloji Araştırma Laboratuvarı'nda standart yöntemlere göre gerçekleştirilmiştir (APHA, 1998).

Sulama suyu açısından Mustafakemalpaşa Çayı'nın değerlendirilmesinde bazı sulama suyu indeksleri uygulanmıştır. Bunlar yüzde sodyum (\% Na) (Wilcox, 1955), sodyum adsorbsiyon oranı 
(SAR) (Wilcox, 1955) ve kalıc1 sodyum karbonat (RSC)'tır (Eaton, 1950). Bu indekslerin hesaplanmasında iyonların meq/L değerleri kullanılmıştır. Ayrıca Mustafakemalpaşa Çayı'nın su kalitesi ABD tuzluluk diyagramına (Richards, 1954) ve Wilcox diyagramına (Wilcox, 1955) göre de değerlendirilmiştir.

Mustafakemalpaşa Çayı suyunda ölçülen çevresel değişkenlere ait analiz sonuçları Yerüstü Su Kalitesi Yönetmeliği (YSKY, 2012) ve Su Ürünleri Yönetmeliği'ne (SÜY, 1995) göre değerlendirilmiştir. Ayrıca Mustafakemalpaşa Çayı suyunun sulama suyu olarak kullanılması nedeni ile Atıksu Arıtma Tesisleri Teknik Usüller Tebliği (AATTUT, 2010) Ek 7; Arıtılmış Atıksuların Sulama Suyu Olarak Geri Kullanım Kriterleri'ne göre de değerlendirilmiştir. Sonuçların değerlendirilmesinde Mustafakemalpaşa Çayı'nda belirlenen iki örnekleme noktasına ait yıllık ortalama değerler ve yıllık maksimum değerler göz önünde bulundurulmuştur.

İstatistiksel analizler

$\mathrm{Bu}$ çalışmada araştırmada veri setini indirgemek, ölçülen çevresel değişkenler arasındaki ilişkileri belirlemek ve çevresel değişkenlerin su kalitesi üzerine muhtemel çevresel baskılarını belirlemek için çok değişkenli istatistiksel yöntemlerden biri olan açımlayıcı faktör analizi (AFA) uygulanmıştır.

Verilerin indirgenmesi ve ilişkili değişkenlerden ilişkisiz ve daha az boyutlu yeni faktör yapıları üretmek faktör analizinin iki temel amacını oluşturmaktadır. Küresellik testi (Bartlett, 1950) korelasyon matriksinin anlamlılığını ölçen bir hipotez testidir. Faktör analizinin geçerli olması için bu testin anlamlı çıkması gerekir $(\mathrm{p}<0,05)$. Kaiser-Meyer-Olkin örneklem yeterliliği testi (KMO) (Kaiser, 1970 ) ise değişkenlerin tutarlılığını ölçen bir ölçüttür ve faktör analizinin uygulanabilmesi için değerinin en azından 0,5'in üzerinde olması istenir (Kaiser, 1974). KMO'nun özel biçimi, her bir değişken için belirlenen örneklem uygunluk ölçüsü (ÖUÖ) değerleridir (Kaiser ve Rice, 1974, Cerny ve Kaiser, 1977). Her bir çevresel değişken için belirlenen ÖUÖ değerleri de KMO gibi değerlendirilmekte ve 0,5 'in altındaki değerler kabul edilmemektedir (Dziuban ve Shirkey, 1974; Kaiser ve Rice, 1974; Cerny ve Kaiser, 1977). Field (2013), ÖUÖ değerleri için sınır değeri 0,5 olarak verirken, Pett vd. (2003) 0,6 değeri üstünün uygun olduğunu söylemektedirler. Bu nedenle düşük ÖUÖ değerleri içeren çevresel değişkenler analizden çıkarılmıştır (Pett vd., 2003). AFA'da varimaks rotasyonu ile veri seti döndürülmüştür. Faktörlerin ekstraksiyonu için ana bileşenler analizi (ABA) uygulanmıştır. Analizler IBM SPSS 22 istatistik paket programında gerçekleştirilmiştir.

\section{BULGULAR}

\section{Mustafakemalpaşa Çayı su kalitesinin ulusal yönetmelikler çerçevesinde değerlendirilmesi}

Mustafakemalpaşa Çayı yüzey suyunda ölçülen çevresel değişkenlere ait analiz sonuçları (minimum, maksimum, yıllık ortalama, standart sapma) bazı yönetmeliklere göre (SÜY, 1995; YSKY, 2012) ve tebliğe göre (AATTUT, 2010) değerlendirilmiş ve sonuçlar Tablo 1'de gösterilmiştir.

Mustafakemalpaşa Çayı suyunda genel çevresel su kalitesi parametrelerinin (sıcaklık, pH, EC, ÇO) EC hariç I. Sınıf kalitede olduğu görülmektedir. Major iyonlardan sadece $\mathrm{SO}_{4}$ ve $\mathrm{Mg}$ iyonlarının SÜY (1995)'e göre tolere değerin üzerinde olduğu tespit edilmiştir. Mustafakemalpaşa Çayı'nda analizi yapılan besin tuzları, ilgili yönetmeliklere göre değerlendirildiğinde ise birçok besin tuzunun limit değerlerin üzerinde olduğu görülmektedir. TN yıllık ortalaması YSKY (2012)'ye göre I. Sınıf su kalitesini gösterirken, $\mathrm{NH}_{4}-\mathrm{N}$ YSKY (2012)'ye göre II. Sınıf su kalitesini işaret etmektedir. Su Ürünleri Yönetmeliği'ne (SÜY, 1995) göre ise tolere değerin üstünde tespit edilen tek besin tuzudur. TP değerleri YSKY (2012)'ye göre III. Sınıf su kalitesindedir. $\mathrm{PO}_{4}-\mathrm{P}$ yıllık ortalama değeri ise YSKY (2012)'ye göre II. Sınıf su kalitesini işaret etmiştir. Ayrıca Mustafakemalpaşa Çayı'nda analizi yapılan metaller YSKY (2012)'ye göre değerlendirildiğinde yedi metalin (B, As, $\mathrm{Hg}, \mathrm{Cr}$, Ni, Al ve $\mathrm{Fe}$ ) y1llık ortalama çevresel kalite standardı (YO) ve/veya maksimum çevresel kalite standardının (MAK) üstünde olduğu görülmektedir (Tablo 1). 
Tablo 1. Mustafakemalpaşa Çayı'nda ölçülen çevresel değişkenlerin minimum, maksimum ve yıllık ortalama değerleri ve bu değerlerin ulusal yönetmeliklere göre değerlendirilmesi.

\begin{tabular}{|c|c|c|c|c|c|c|c|c|}
\hline & Birim & Min. & Maks. & $\begin{array}{c}\text { Yıllık } \\
\text { Ortalama }\end{array}$ & $\begin{array}{l}\text { Standart } \\
\text { Sapma }\end{array}$ & $\begin{array}{l}\text { YSKY } \\
2012 * *\end{array}$ & SÜY 1995 & $\begin{array}{c}\text { AATTUT } \\
2010\end{array}$ \\
\hline Sicakl1k & ${ }^{\circ} \mathrm{C}$ & 5,67 & 24,50 & 14,71 & 6,37 & - & - & - \\
\hline $\mathrm{pH}$ & & 8,02 & 8,66 & 8,35 & 0,15 & I.sinif & - & - \\
\hline $\mathrm{EC}$ & $\mu \mathrm{S} / \mathrm{cm}$ & 340,00 & 845,00 & 639,25 & 154,28 & II.sınıf & - & KZD yok \\
\hline $\mathrm{ÇO}$ & $\mathrm{mg} / \mathrm{L}$ & 4,10 & 15,20 & 9,64 & 2,68 & I.sinif & - & - \\
\hline Bulanıklık & NTU & 7,25 & 96,60 & 35,64 & 20,29 & - & - & - \\
\hline $\mathrm{HCO}_{3}$ & $\mathrm{mg} / \mathrm{L}$ & 94,55 & 408,70 & 210,91 & 101,83 & - & - & - \\
\hline $\mathrm{CO}_{3}$ & $\mathrm{mg} / \mathrm{L}$ & 9,60 & 91,20 & 30,70 & 18,04 & - & - & - \\
\hline AKM & $\mathrm{mg} / \mathrm{L}$ & 0,30 & 141,80 & 19,14 & 30,91 & - & - & - \\
\hline $\mathrm{TH}$ & $\mathrm{F}^{\mathrm{o}}$ & 10,00 & 37,60 & 21,16 & 8,45 & - & - & - \\
\hline $\mathrm{NO}_{2}-\mathrm{N}$ & $\mu \mathrm{g} / \mathrm{L}$ & 3,04 & 93,13 & 27,84 & 31,25 & - & TD altında & - \\
\hline $\mathrm{NO}_{3}-\mathrm{N}$ & $\mu \mathrm{g} / \mathrm{L}$ & 197,67 & 1176,07 & 534,98 & 242,02 & I.sinif & TD altında & - \\
\hline $\mathrm{NH}_{4}-\mathrm{N}$ & $\mu \mathrm{g} / \mathrm{L}$ & 13,64 & 1116,28 & 202,77 & 285,75 & II.sinıf & TD üstünde & - \\
\hline $\mathrm{PO}_{4}-\mathrm{P}$ & $\mu \mathrm{g} / \mathrm{L}$ & 51,54 & 267,61 & 123,28 & 60,73 & II.sInıf & TD altında & - \\
\hline $\mathrm{TN}$ & $\mu \mathrm{g} / \mathrm{L}$ & 702,55 & 2605,85 & 1498,65 & 477,95 & I.sinif & - & - \\
\hline $\mathrm{TP}$ & $\mu \mathrm{g} / \mathrm{L}$ & 117,60 & 355,17 & 202,74 & 65,13 & III.sınıf & - & - \\
\hline $\mathrm{SO}_{4}$ & $\mathrm{mg} / \mathrm{L}$ & 33,41 & 149,04 & 93,88 & 35,97 & - & TD üstünde & - \\
\hline $\mathrm{SiO}_{2}$ & $\mathrm{mg} / \mathrm{L}$ & 0,43 & 1,12 & 0,66 & 0,15 & YO altında & - & - \\
\hline $\mathrm{Cl}$ & $\mathrm{mg} / \mathrm{L}$ & 7,12 & 29,07 & 14,73 & 6,80 & - & TD altında & - \\
\hline $\mathrm{Na}$ & $\mathrm{mg} / \mathrm{L}$ & 9,17 & 30,72 & 17,42 & 6,55 & - & TD altında & - \\
\hline $\mathrm{K}$ & $\mathrm{mg} / \mathrm{L}$ & 1,61 & 6,90 & 3,05 & 1,13 & - & TD altında & - \\
\hline $\mathrm{Mg}$ & $\mathrm{mg} / \mathrm{L}$ & 18,09 & 60,77 & 43,55 & 12,47 & - & TD üstünde & - \\
\hline $\mathrm{Ca}$ & $\mathrm{mg} / \mathrm{L}$ & 21,97 & 71,34 & 50,43 & 11,63 & - & TD altında & - \\
\hline $\mathrm{F}$ & $\mu \mathrm{g} / \mathrm{L}$ & 80,00 & 330,00 & 160,00 & 60,00 & I.sinif & TD altında & $\begin{array}{l}\text { IVMK } \\
\text { altında }\end{array}$ \\
\hline B & $\mathrm{mg} / \mathrm{L}$ & 1,31 & 20,86 & 9,32 & 6,32 & $\begin{array}{c}\text { MAK } \\
\text { üstünde YO } \\
\text { üstünde } \\
\end{array}$ & TD üstünde & $\begin{array}{c}\text { İVMK } \\
\text { üstünde \# }\end{array}$ \\
\hline As & $\mu \mathrm{g} / \mathrm{L}$ & 16,75 & 167,96 & 85,85 & 47,71 & $\begin{array}{c}\text { MAK } \\
\text { üstünde YO } \\
\text { üstünde }\end{array}$ & TD altında & $\begin{array}{l}\text { İVMK } \\
\text { altında }\end{array}$ \\
\hline $\mathrm{Sb}$ & $\mu \mathrm{g} / \mathrm{L}$ & 0,49 & 1,39 & 0,89 & 0,27 & YO altında & - & - \\
\hline $\mathrm{Cu}$ & $\mu \mathrm{g} / \mathrm{L}$ & 1,07 & 2,81 & 1,45 & 0,40 & YO altında & TD altında & $\begin{array}{l}\text { IVMK } \\
\text { altında }\end{array}$ \\
\hline $\mathrm{Hg}$ & $\mu \mathrm{g} / \mathrm{L}$ & $<0,06$ & 1,54 & 0,14 & 0,30 & $\begin{array}{c}\text { MAK } \\
\text { üstünde }\end{array}$ & TD altında & - \\
\hline $\mathrm{Cr}$ & $\mu \mathrm{g} / \mathrm{L}$ & 2,78 & 6,83 & 4,76 & 1,34 & $\begin{array}{c}\text { MAK } \\
\text { altında YO } \\
\text { üstünde } \\
\end{array}$ & TD altında & $\begin{array}{l}\text { IVMK } \\
\text { altında }\end{array}$ \\
\hline $\mathrm{Pb}$ & $\mu \mathrm{g} / \mathrm{L}$ & $<0,15$ & 0,23 & 0,16 & 0,02 & YO altında & TD altında & $\begin{array}{l}\text { İVMK } \\
\text { altında } \\
\end{array}$ \\
\hline $\mathrm{Ni}$ & $\mu \mathrm{g} / \mathrm{L}$ & 3,93 & 12,00 & 6,09 & 1,86 & $\begin{array}{c}\text { MAK } \\
\text { altında YO } \\
\text { üstünde } \\
\end{array}$ & TD altında & $\begin{array}{l}\text { İVMK } \\
\text { altında }\end{array}$ \\
\hline $\mathrm{Se}$ & $\mu \mathrm{g} / \mathrm{L}$ & 0,36 & 0,58 & 0,40 & 0,07 & I.sinif & TD altında & $\begin{array}{l}\text { İVMK } \\
\text { altında } \\
\end{array}$ \\
\hline
\end{tabular}




\begin{tabular}{ccccccccc}
\hline $\mathrm{Al}$ & $\mu \mathrm{g} / \mathrm{L}$ & 120,47 & 5881,54 & 1054,86 & 1529,87 & $\begin{array}{c}\text { MAK } \\
\text { üstünde Yo } \\
\text { üstünde }\end{array}$ & TD üstünde & $\begin{array}{c}\text { IVMK } \\
\text { altında }\end{array}$ \\
\hline $\mathrm{Fe}$ & $\mu \mathrm{g} / \mathrm{L}$ & 146,61 & 2865,14 & 793,89 & 873,98 & $\begin{array}{c}\text { MAK } \\
\text { üstünde YO } \\
\text { üstünde }\end{array}$ & TD üstünde & $\begin{array}{c}\text { IVMK } \\
\text { altında }\end{array}$ \\
\hline $\mathrm{Mn}$ & $\mu \mathrm{g} / \mathrm{L}$ & 18,10 & 137,02 & 53,97 & 32,24 & I.sinıf & TD altında & $\begin{array}{c}\text { IVMK } \\
\text { altında }\end{array}$ \\
\hline$\% \mathrm{Na}$ & $\%$ & 7,20 & 17,04 & 10,76 & 2,25 & - & - & - \\
\hline $\mathrm{RSC}$ & $\mathrm{meq} / \mathrm{L}$ & $-3,83$ & 1,01 & $-1,62$ & 1,55 & - & - & - \\
\hline $\mathrm{SAR}$ & $\mathrm{meq} / \mathrm{L}$ & 0,30 & 0,75 & 0,43 & 0,13 & - & - & - \\
\hline \hline
\end{tabular}

Yönetmeliklerde azot bileşikleri farklı formlarda değerlendirilmektedir. Bu durumda hangi formunda verilmişse dönüşümler yapılarak verilen değer üzerinden değerlendirme yapılmıștır.

**Yönetmelikte 2016 yılında yapılan değişiklik sonucu eklenen Ek 5, Tablo 2,4 ve 5'e göre değerlendirilmiştir. SD: sinır değerler

YO: yıllık ortalama çevresel kalite standardı

MAK: maksimum çevresel kalite standardı

KZD: Kullanımda zarar derecesi

TD: Tolere değer

IVMK: İzin verilen maksimum konsantrasyon

\#Bora çok toleranslı (> $4 \mathrm{mg} / \mathrm{L}$ ) bitkiler için dahi çok üst bir değer

Mustafakemalpaşa Çayı suyu, Mustafakemalpaşa Ovası'nın sulanmasında kullanıldığı için yüzey suyu bazı sulama indeksleri açısından da değerlendirilmiş ve bu bulgular da Tablo 1'de verilmiştir. Çalışmada hesaplanan \% $\mathrm{Na}$ değerinin hem maksimum hem de yıllık ortalama derişimi değerinin 20 'nin altında ve SAR değerinin de 10'un altında belirlenmesi sulama suyu kalitesinin I. Sınıf olduğunu göstermektedir (Richards, 1954) Mustafakemalpaşa Çayı RSC indeksi açısından değerlendirildiğinde ise yıllık ortalama değer -1,62 olarak tespit edilmiştir. İndeks değerinin 0'1n altında bir değerde çıkması sodyumun olumsuz etkisinin olmadığını ifade etmektedir (Eaton 1950; Hopkins vd., 2007). Sulama suyu sınıfı ABD tuzluluk laboratuvarı grafik sistemine göre değerlendirildiğinde (Richards, 1954) su kalitesi C2-S1 (orta tuzlulukta ve az sodyumlu) çıkmaktadır. Wilcox diyagramına (Wilcox, 1955) göre ise su kalitesi çok iyi sınıfinda belirlenmiştir. Bu bulgular akarsuyun sulama suyu kalitesinin yüksek bor derişimi dışında iyi kalitede olduğunu göstermektedir (AATTUT, 2010).

\section{Faktör analizi sonuçları}

Tüm çevresel değişkenlerin kullanıldığı analizler (ABA/AFA) sonucunda her bir değişken için belirlenen örneklem uygunluk ölçüsü (ÖUÖ) değerleri kontrol edilmiş ve 0,6 altında ÖUÖ değerine sahip değişkenler analizden çıkarılmıştır (Pett vd., 2003). Son ABA/AFA veri setinde 15 çevresel değişken kullanılmış ve KMO değeri 0,771 olarak belirlenmiştir. Kaiser (1974) 0,7 üzerinde bulunan KMO değerlerinin orta seviyede kabul edilebilen bir değer olduğunu söylemekte olup, KMO değeri 0,5 altında olduğunda ise veri setinin faktör analizi için uygun olmadığını söylemektedir. Bartlett küresellik testi (Bartlett, 1950) sonucunda ise alternatif hipotez kabul edilmiş $\left(X^{2}: 349,27 ; d f: 105 ; p\right.$ : $0,000)$ ve AFA'nın bu veri seti için uygun olduğuna karar verilmiştir.

Uygun faktör sayısını belirlemek için yamaç eğim testi uygulanmış (Cattell, 1966), faktörlerin özdeğerlerinin $(\lambda)$ değişimi yamaç eğim grafiğginde verilmiştir (Şekil 2). Özdeğeri ( $\lambda$ ) 1'den büyük olan ilk üç faktör uygun faktörler olarak belirlenmiştir (Kaiser kriteri). Ayrıca ilk üç faktör toplamı \% 76,426 olmuş (Tablo 2) ve açıklanan varyans kriteri için istenen \% 67 sınırı da (açıklanan varyansın en az 2/3'ü) aş1lmıştır.

$\mathrm{ABA} / \mathrm{AFA}$ ile elde edilen tahminlenmiş ve döndürülmüş faktörlerin özdeğerleri $(\lambda)$, toplam varyans ve yığılmalı (kümülatif) varyans sonuçları Tablo 2'de verilmiş, ilk üç faktörün \% varyans değerlerinin birbirine yakın değerler olduğu ve üç faktörden birinin diğerlerine baskın olmadığı tespit edilmiştir. İlk faktör toplam varyansın \% 28,760'sın1, ikinci faktör \%25,99'unu ve üçüncü faktör ise \% 21,667'sini oluşturmuştur. Değişkenlerin hangi faktörle ilişki içerisinde olduğunu gösteren döndürülmüş faktör matriksi Tablo 3'te verilmiş, bu değişkenlerin üç boyutlu gösterimi ise Şekil 3'te verilmiştir. İlk faktörde $\mathrm{HCO}_{3}, \mathrm{~B}$, As değişkenlerinin çok kuvvetli pozitif yük oluşturduğu $\mathrm{Sb}$, $\mathrm{Na}$ ve $\mathrm{Ca}$ değişkenlerinin ise kuvvetli pozitif yük oluşturduğu Tablo 3'te görülmektedir. İkinci faktörde ise $\mathrm{Fe}$, $\mathrm{Al}$ ve $\mathrm{TN}$ çok kuvvetli negatif yük oluşturuken, $\mathrm{Mg}, \mathrm{SO}_{4}$ ve $\mathrm{Ca}$ kuvvetli pozitif yük oluşturmuştur. 
Üçüncü faktörde ise $\mathrm{F}, \mathrm{PO}_{4}-\mathrm{P}, \mathrm{Si}, \mathrm{SO}_{4}, \mathrm{Sb}$ ve $\mathrm{Na}$ kuvvetli pozitif yük, $\mathrm{DO}$ ise kuvvetli negatif yük oluşturmuştur (Tablo 3).

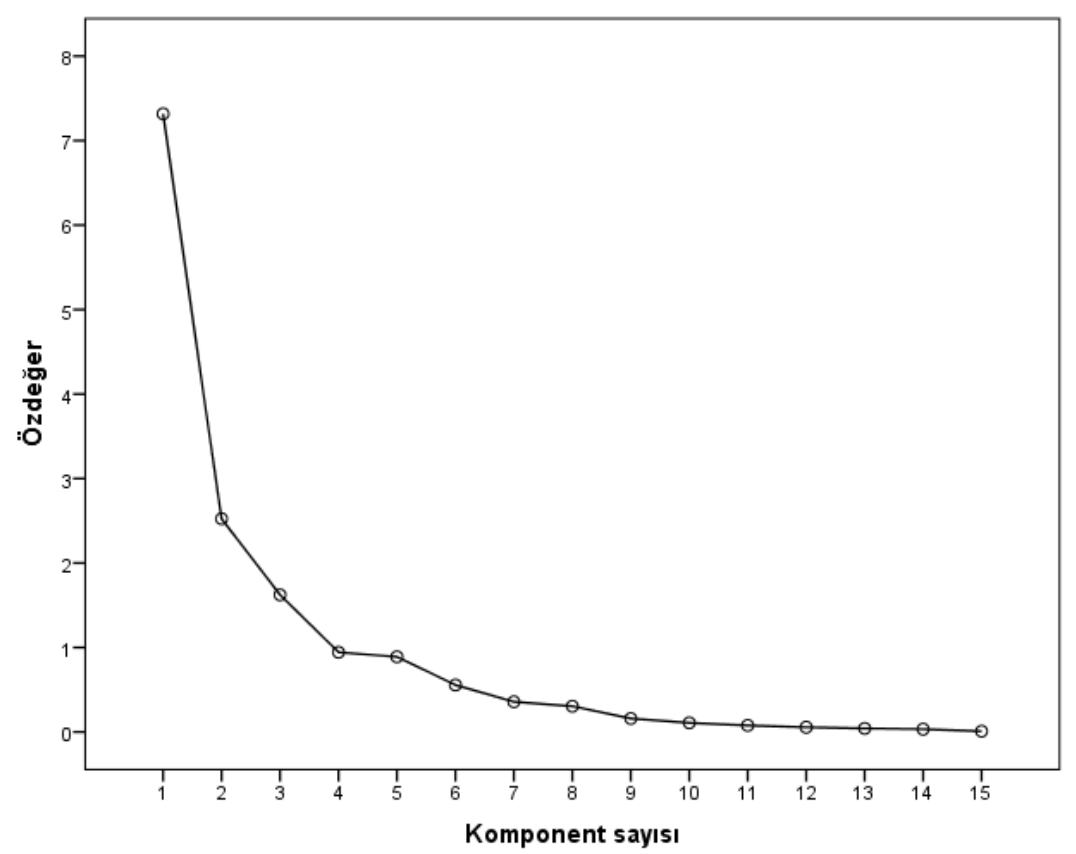

Şekil 2. Özdeğerlerin yamaç eğim grafiğ

Tablo 2. Toplam varyans tablosu

\begin{tabular}{|c|c|c|c|c|c|c|c|c|c|}
\hline \multirow[b]{2}{*}{ Faktör } & \multicolumn{3}{|c|}{ Başlangıç Özdeğerler } & \multicolumn{3}{|c|}{$\begin{array}{l}\text { Tahminlenmiş Yüklerin } \\
\text { Kareler Toplamı }\end{array}$} & \multicolumn{3}{|c|}{$\begin{array}{l}\text { Döndürülmüss Yüklerin } \\
\text { Kareler Toplamı }\end{array}$} \\
\hline & Toplam & $\begin{array}{c}\% \\
\text { Varyans }\end{array}$ & $\begin{array}{c}\% \\
\text { Yığılmalı } \\
\text { Varyans }\end{array}$ & Toplam & $\begin{array}{c}\% \\
\text { Varyans }\end{array}$ & $\begin{array}{c}\% \\
\text { Yığılmalı } \\
\text { Varyans }\end{array}$ & Toplam & $\begin{array}{c}\% \\
\text { Varyans }\end{array}$ & $\begin{array}{c}\% \\
\text { Yığılmal } \\
\text { Varyans }\end{array}$ \\
\hline 1 & 7,318 & 48,784 & 48,784 & 7,318 & 48,784 & 48,784 & 4,314 & 28,760 & 28,760 \\
\hline 2 & 2,523 & 16,822 & 65,605 & 2,523 & 16,822 & 65,605 & 3,900 & 25,999 & 54,759 \\
\hline 3 & 1,623 & 10,821 & 76,426 & 1,623 & 10,821 & 76,426 & 3,250 & 21,667 & 76,426 \\
\hline
\end{tabular}

Tablo 3. Döndürülmüş faktör matriksi sonuçları

\begin{tabular}{lccc}
\hline & & Faktörler \\
& & $\mathbf{1}$ & $\mathbf{3}$ \\
\hline $\mathrm{DO}$ & & & $-0,683$ \\
$\mathrm{HCO}_{3}$ & 0,917 & & \\
$\mathrm{Si}$ & & & 0,655 \\
$\mathrm{SO}_{4}$ & & 0,665 & 0,520 \\
$\mathrm{Na}$ & 0,647 & & 0,504 \\
$\mathrm{Mg}$ & & 0,717 & \\
$\mathrm{Ca}$ & 0,591 & 0,504 & \\
$\mathrm{PO}{ }_{4}-\mathrm{P}$ & & & 0,735 \\
$\mathrm{TN}$ & & $-0,811$ & \\
$\mathrm{~F}$ & & & 0,801 \\
$\mathrm{~B}$ & 0,913 & & \\
$\mathrm{As}$ & 0,863 & & \\
$\mathrm{Sb}$ & 0,700 & & 0,511 \\
$\mathrm{Al}$ & & $-0,837$ & \\
$\mathrm{Fe}$ & & $-0,890$ & \\
\hline \hline
\end{tabular}




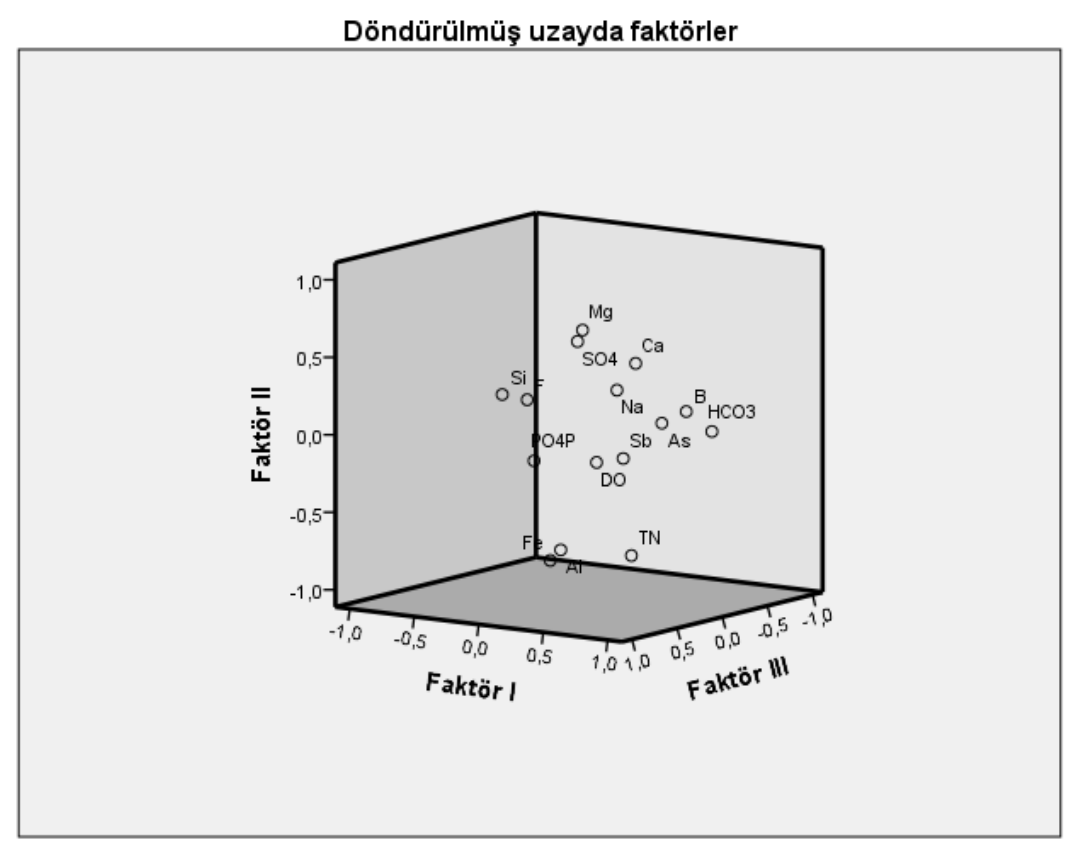

Şekil 3. Döndürülmüş faktör matriksinin bileşen yükleri

\section{TARTIŞMA ve SONUÇ}

$\mathrm{Bu}$ çalışmada $\mathrm{ABA} / \mathrm{AFA}$ kullanılarak değişkenlerin faktörler ile gruplara ayrılması sağlanmış ve su kalitesi üzerine muhtemel çevresel baskılar açıklanmaya çalışılmıştır. Faktör analizi sonuçları Mustafakemalpaşa Çayı'nda madencilik faaliyetleri ve havzanın jeolojik yapısının akarsuyun su kalitesi üzerinde büyük etkisinin olduğunu göstermektedir. Özellikle ilk üç faktörde faktör yükü oluşturan $\mathrm{B}, \mathrm{As}, \mathrm{Sb}, \mathrm{F}, \mathrm{Al}$ ve $\mathrm{Fe}$ metalleri ve $\mathrm{HCO}_{3}, \mathrm{Si}, \mathrm{SO}_{4}, \mathrm{Na}, \mathrm{Mg}$, F ve Ca iyonlarının faktör yükü oluşturmaları bu durumun kanıtıdır. Kütahya, ülkemizin maden kaynakları açısından en zengin illerinden biridir. Bu madenlerin başında bor madeni gelmektedir. Bor iyonik yapısı nedeni ile hiçbir zaman tek başına bulunmaz, diğer elementler ve oksijen ile bor tuzlarını oluşturur (Helvacı, 2015a). Günümüzde 250'den fazla borat minerali tanımlanmıştır (Helvacı, 2015a). Kütahya Emet'te ETİ Maden tarafından işletilen maden yatağında $\mathrm{Ca}$ boratlar, $\mathrm{Ca} / \mathrm{Na}$ boratlar, $\mathrm{Mg}$ boratlar ve As boratlar bulunmaktadır (Helvac1, 2003). Borat minerallerinden Ca boratlardan kolemanit ve $\mathrm{Ca} / \mathrm{Na}$ boratlardan üleksit Emet Çayı'na kıyısı bulunan maden yatağından ekonomik olarak çıkarılmaktadır. İlk iki faktörde faktör yükü oluşturan $\mathrm{Na}, \mathrm{Ca}$ ve $\mathrm{Mg}$ ile $\mathrm{B}$ ve As metallerinin faktör analizinde önemli faktör yükü oluşturmasının sebebinin bor madenciliği ile ilişkili olduğu görülmektedir.

Havzanın jeolojik yapısının da faktör yükü oluşumunda önemli olduğu, genellikle bor ile birlikte bulunan bazı minerallerin yapısında bulunan $\mathrm{Ca}, \mathrm{Mg}, \mathrm{HCO}_{3}, \mathrm{SO}_{4}, \mathrm{Si}$ ve As gibi elementlerin (Helvac1, 1984; Helvac1 vd., 1993; Helvac1, 2015a) ve havzada maden rezervlerinde bulunan bazı minerallerin yapisinda bulunan $\mathrm{Fe}, \mathrm{Al}, \mathrm{F}, \mathrm{Sb}$ gibi elementlerin (MTA, 2010a) yine istatistiksel analizlerde (ABA/AFA) faktör yükü oluşturduğu tespit edilmiştir.

ABA/AFA'da faktör yükü oluşturan bazı iyon ve metallerin ulusal yönetmeliklere göre sınır değerleri aştığı tespit edilmiştir. Faktör analizinde I. ve II. faktörlerde kuvvetli faktör yükü oluşturan $\mathrm{B}$, As, Al ve Fe ağır metallerinin y1llık ortalama ve y1llık maksimum değerlerinin YSKY (2012)'ye göre limit değerin üstünde tespit edilmiştir. As dışında diğer üç ağır metal aynı zamanda Su Ürünleri Yönetmeliği'ne (SÜY, 1995) göre de tolere değerin üstünde bulunmuştur. $\mathrm{Mg}$ ve $\mathrm{SO}_{4}$ iyonlarının yıllık ortalama derişimi Su Ürünleri Yönetmeliği'ne göre (SÜY, 1995) tolere değerin üstünde tespit edilmiş, diğer iyonlar ise sınır değerleri aşmamıştır. ABA/AFA'da faktör yükü oluşturan Florürün ise ulusal yönetmeliklere göre sınır değerler içinde olduğu tespit edilmiştir. Ancak Tavşanlı' da bulunan florit yatağının geçmiş yıllarda işletilmesi nedeni ile (MTA, 2010a) bu elementin de sürekli izlenmesi gerekmektedir.

ABA/AFA'da faktör yükü oluşturmamış bazı metallerin de ulusal yönetmeliklere göre sınır değerleri aştığı tespit edilmiştir. Cr ve Ni ağır metallerinin yıllık ortalama derişimleri YSKY (2012)'ye göre yıllık ortalama değerin üzerinde, ancak yıllık maksimum değerin altında kaydedilmiştir. Hg 
derişimi ise yıllık maksimum seviyenin üzerinde tespit edilmiştir. Kütahya havzasında ve Bursa Orhaneli'de bulunan krom madenlerinden kaynaklı atıkların takip edilmesi gerektiği ve bu madenlerden kaynaklı kirliliğin ileriki yıllarda havzada kirliliğe yol açabileceği ve risk faktörü olduğu düşünülmektedir. Ağır metallerden $\mathrm{Sb}, \mathrm{Cu}, \mathrm{Se}, \mathrm{Pb}$ ve $\mathrm{Mn}$ ise yönetmeliklere göre sinır değerlerinin altında bulunmuş ya da I. sınıf su kalitesinde tespit edilmiştir. Bu ağır metaller sınır değerler içinde belirlenmesine rağmen havzada gerçekleştirilen madencilik faaliyetleri ve havzanın jeolojik yapısı nedeni ile sürekli takip edilmesi gerektiği düşünülmektedir. Mustafakemalpaşa Çayı'nın beslediği Uluabat Gölü'nde daha önceki yıllarda yapılan çalışmalar göl suyunda, sedimanda ve gölde yaşayan canlıların dokularında (Elmacı vd., 2007; Arslan vd., 2010) Cd, Cr, Pb, Cu, ve Ni seviyelerinin sınır değerlerin üzerinde olduğunu göstermiştir.

Yapılan araştırmalar özellikle son 15 yıldır Emet Çayı'nda çok yüksek B derişimlerinin gözlendiğini göstermektedir (Çöl ve Çöl 2003; Semiz, 2014; Tokatlı vd., 2016; Benzer, 2017). Omwene vd. (2019) havzadaki bor kirliliğinin temel kaynağının Emet Çayı olduğunu belirlemişler, Emet Çayı üst havzasında $B$ derişiminin $50 \mathrm{mg} / \mathrm{L}$ 'nin üzerinde olduğunu ve $B$ derişiminin üst havzadan alt havzaya doğru giderek azaldığını tespit etmiş̧lerdir. Bu durum Emet Çayı vasıtası ile bor kirliliğinin Mustafakemalpaşa Çayı'na taşındığının bir kanıtıdır. Bu çalışmada Mustafakemalpaşa Çayı'nda B yıllık ortalaması 9,32 mg/L olmuş ve 20,86 mg/L olarak 24 Ekim 2016'da Döllük örnekleme noktasında en yüksek derişimde belirlenmiş, bu ayda Ayazköy noktasındaki derişim ise $19,93 \mathrm{mg} / \mathrm{L}$ olmuştur. Mustafakemalpaşa Çayı 2015 yılından beri BUSKİ tarafından yılda 4 defa iki örnekleme noktasında örnekleme yapılarak izlenmektedir (BUSKİ, 2019). Bu verilere göre (BUSKİ, 2019) B derişimi 06.10.2016 tarihinde Emet ve Orhaneli çayları karışımı sonrasında 21,792 mg/L olarak ölçülmüş, yine bu tarihte Mustafakemalpaşa Çayı'nın Uluabat Gölü'ne döküldüğü noktada ise $17,927 \mathrm{mg} / \mathrm{L}$ olarak tespit edilmiştir. Y1llık ortalama B derişimi AATTUT (2010)'a göre yüksek B derişimini tolere edebilen bitkiler $(>4,0 \mathrm{mg} / \mathrm{L})$ için yüksek bir değerdir ve bu bitkilerde dahi toksik etki oluşturabilecek seviyededir. Mustafakemalpaşa Ovası'nda üretimi yapılan en önemli sebze domatesdir ve Mustafakemalpaşa Çayı'ndan alınan su ile sulama gerçekleştirilmektedir. Uysal vd. (2017), Mustafakemalpaşa ilçesinde yetişen domateslerin yapraklarında ve toprakta bor analizleri yapmışlar ve örneklerin \% 65'inde toprak bor içeriklerini $2,0 \mathrm{mg} / \mathrm{kg}$ değerinin üzerinde bulmuşlar, bazı alanlarda ise kritik seviye olan $5 \mathrm{mg} / \mathrm{kg}$ B seviyesine çok yaklaştığını tespit etmişleridir. Yaprak örneklerinde ise $100 \mathrm{mg} / \mathrm{kg}$ olan üst sınırın üzerinde bulunan alanların oranını \% 80 olarak tespit etmişlerdir (Uysal vd., 2017). Bu bulgular Mustafakemalpaşa Çayı'ndan alınan su ile sulanan tarlalarda toprakta ve bitkilerde yüksek bor birikimi olduğunun bir göstergesidir.

As uzun y1llardan beri Uluabat Gölü alt havzasında kirlilik oluşturan önemli bir metaldir. Daha önceki yıllarda yapılan çalışmalar, Emet ve Hisarcık bölgelerinde yüzey ve yeraltı sularında içme sularında izin verilen seviyenin $(<10 \mu \mathrm{g} / \mathrm{L})$ çok üzerinde As derişimleri bulunduğunu (Çolak vd. 2003; Çöl ve Çöl 2004; Tokatlı vd., 2016; Benzer 2017) ve bu suları tüketen yöre halkında deri lezyonları ve cilt kanseri bulguları gözlendiğini göstermektedir (Çöl vd., 1999; Doğan vd., 2005). Omwene vd. (2019), Emet Çayı üst havzasında As derişiminin $200 \mu \mathrm{g} / \mathrm{L}$ 'nin üzerinde olduğunu belirlemişlerdir. Çolak vd. (2003) Emet bölgesinde yüzey ve yeraltısularında tespit edilen yüksek As derişiminin temel sebebinin kolemanit nodülleri içinde bulunan realgar (AsS) ve orpiment $\left(\mathrm{As}_{2} \mathrm{~S}_{3}\right)$ minerallerinden kaynaklandığını ifade etmektedirler. Bu minerallerin yanında As-boratlardan terrujit ve kahnitin Emet borat yataklarında bulunması (Helvac1, 2003) bu havzadaki yüksek As derişiminin bir diğer nedenidir. Omwene vd. (2019) Orhaneli Çayı'nda Kütahya-Tavşanlı bölgesinde As derişiminin 50-100 $\mu \mathrm{g} / \mathrm{L}$ aralığında bulunduğunu tespit etmişlerdir. Şener ve Karakuş (2017) KütahyaTavşanlı'nın $3 \mathrm{~km}$ doğusunda Gözeçukuru As-Sb-Pb-Zn maden bölgesinde yapılan madencilik aktiviteleri nedeni ile Tavşanlı bölgesinde yüzey sularında As seviyesinin yeraltı sularından daha yüksek bulunduğunu söylemektedirler. Arslan ve Çelik (2015) Gözeçukuru maden alanının hemen yakınında bulunan gümüş madeni atık havuzunun $\mathrm{As}, \mathrm{Pb}$ ve $\mathrm{Sb}$ bakımından zengin olduğunu ve bu atıkların maden havuzundan sızması sonucu yüzey sularının kirlendiğini söylemektedirler. Arseniğin içme suyundaki limit değeri $10 \mu \mathrm{g} / \mathrm{L}$ 'dir (TSE, 2005). AATTUT (2010)'ye ve SÜY (1995)'e göre ise tolere değer $100 \mu \mathrm{g} / \mathrm{L}$ 'dir. Mustafakemalpaşa Çayı'nda yıllık ortalama As derişimi 85,85 $\mu \mathrm{g} / \mathrm{L}$ olmuş, bazı aylarda arsenik derişiminin $160 \mu \mathrm{g} / \mathrm{L}$ 'nin üzerine çıtığı tespit edilmiştir. Mustafakemalpaşa Çayı'ndaki As bulguları havzada yapılan çeşitli çalışmalar ile karşılaştırıldığında, çaydaki yüksek As 
derişiminin ana kaynağının Emet Çayı olduğu, daha az oranda As girdisinin ise Orhaneli Çayı'ndan kaynaklandığ 1 görülmektedir.

Mustafakemalpaşa Çayı'nda kirliliğe sebep olan metallerden bir diğeri demirdir. Yıllık ortalaması $793,89 \mu \mathrm{g} / \mathrm{L}$ olarak tespit edilmiş ve YSKY (2012) ve SÜY (1995)'e göre bu değerlerin tolere edilebilir değerin üzerinde olduğu görülmüştür. Yıllık maksimum derişim ise $2800 \mu \mathrm{g} / \mathrm{L}$ 'nin üzerinde bulunmuştur. Mustafakemalpaşa Çayı'nda bu değerden daha yüksek Fe değerleri daha önceki yıllarda tespit edilmiştir. BUSKİ (2019) verilerine göre Fe derişimi özellikle kış aylarında dönemsel olarak yüksek seviyelere çıkmaktadır (Ör: 14.01.2016 tarihinde sırasıyla 21,619 mg/L ve 22,397 mg/L). Dalkıran (2006) Orhaneli Çayı'nda yaptığı çalışmada Fe derişiminin $0,03-4,71 \mathrm{mg} / \mathrm{L}$ aralığında değiştiğini tespit etmiştir. Karacaoğlu (2006) Emet Çayı'nda Fe derişiminin 0,01 mg/L ile 20,5 mg/L arasında değiştiğini bildirmiştir. Bu değerler Orhaneli Çayı'nda tespit edilen değerlerden çok daha yüksek değerlerdir. Bu bulgular Mustafakemalpaşa Çayı'ndaki yüksek Fe derişiminin Orhaneli ve özellikle Emet Çayı kaynaklı olduğunu göstermektedir. Bunun en önemli nedeni olarak yine bölgenin jeolojik yapısı öne çıkmaktadır. Kütahya ilinde Emet ve Simav ilçelerinde yüksek demir zuhurları bulunmaktadır (MTA, 2010a). Bu zuhurlar yüksek S, As ve Si içerikleri nedeni ile işletilmemektedir (MTA, 2010a).

Alüminyum çalışma alanında yüksek derişimde tespit edilen diğer bir ağır metal olmuştur. Mustafakemalpaşa Çayı'nda yıllık ortalama derişimi $1054,86 \mu \mathrm{g} / \mathrm{L}$ olmuş, yıllık maksimum derişimi $5800 \mu \mathrm{g} / \mathrm{L}$ 'nin (Ocak 2017 Döllük örnekleme noktası) üzerine çıkmış, yönetmeliklere göre maksimum ve tolere değerlerin üzerinde tespit edilmiştir. BUSKİ (2019) verilerine göre de Mustafakemalpaşa Çayı'nda Al derişimi özellikle kış aylarında daha yüksek değerlere çıkmaktadır (ör: 14.01.2016 tarihinde sırasıyla 28,781 ve $29,355 \mathrm{mg} / \mathrm{L}$ ). BUSKİ verileri dışında her üç akarsuda eski yıllara ait Al derişimi ile ilgili herhangi bir bulguya ulaşılamamıştır. Havzadaki yüksek Al derişiminin sebebi olarak yine havzanın madencilik faaliyetleri ve jeolojik yapısı ön plana çıkmaktadır. Kütahya ilinde feldispat gibi Al içeren mineraller bulunmaktadır (MTA, 2010a). Emet borat yataklarında bulunan tüf ve tüflü kayalarda da \% 12,55- 13,88 oranında Alünit $\left(\mathrm{Al}_{2} \mathrm{O}_{3}\right)$ bulunmaktadır (Helvac1 vd., 1993). Ayrıca Kütahya-Gediz'de Şaphane Sahasında bulunan tenör \% 19,2 alunit içermekte ve yatak işletilmektedir (MTA, 2010a). Şaphane Dağı Emet Çayı'nın kaynağının bulunduğu bölgedir. Bu bulgular bize Mustafakemalpaşa Çayı'ndaki Al kirliliğinin sebebinin Emet Çayı kaynaklı olduğunu düşündürmektedir. Ayrıca Emet ve Mustafakemalpaşa çaylarında yüksek Al ve Fe içeriğinin bir diğer sebebi olarak bor madenciliğinin de katkıs1 olduğu düşünülmektedir. Erdoğan vd. (2004), kolemanit atıklarında yaş ağırlıkta sırasıyla \% 3,73 ve \% 1,90 oranında $\mathrm{Al}_{2} \mathrm{O}_{3}$ ve $\mathrm{Fe}_{2} \mathrm{O}_{3}$ bulunduğunu söylemektedirler.

Mustafakemalpaşa Çayı yıllık ortalama TN derişimi YSKY (2012)'de belirlenen I. Sınıf su sınır değerinin $(<3,5)$ yaklaşık yarısı kadardır (Tablo 1) ve TN yıllık ortalama değerlerine göre Mustafakemalpaşa Çayı su kalitesi I. Sınıftır. Dodds vd. (1998) yaptıkları bir araştırmada, yıllık ortalama TN değerini mezotrofik-ötrofik sınır değerinin $(1,5 \mathrm{mg} / \mathrm{L})$ altında, ancak oligotrofikmezotrofik sınır değerinin $(0,7 \mathrm{mg} / \mathrm{L})$ üstünde tespit etmişlerdir. Bulgularımıza göre, akarsuyun yıllık ortalama TN derişimi açısından değerlendirildiğinde mezotrofik, ancak yıllık maksimum TN derişimi açısından değerlendirildiğinde ise ötrofik karakterdedir. TP yıllık ortalama değeri ise III. Sınıf su kalitesini gösterirken, Dodds vd. (1998)'e göre de mezotrofik-ötrofik sınır değerinin $(0,075 \mathrm{mg} / \mathrm{L})$ yaklaşık 2,5 kat üzerinde bulunmuş ve akarsuyun TP açısından ötrofik karakterde olduğunu işaret etmiştir. Mustafakemalpaşa Çayı hassas su kütlesi (ötrofik olduğu belirlenen veya yakın gelecekte ötrofik olabilecek su kütlesi) olduğu Mülga Orman ve Su İşleri Bakanlığı tarafından yapılan çalışmalar ile ortaya konmuş (HSKY, 2016) ve bu konuda alınacak önlemler belirlenmiştir.

Mustafakemalpaşa Çayı $\mathrm{NH}_{4}-\mathrm{N}$ ve $\mathrm{NO}_{2}-\mathrm{N}$ açısından sırası ile II. ve III. sınıf su kalitesinde tespit edilmiştir, $\mathrm{NO}_{3}-\mathrm{N}$ değeri açısından ise I. Sınıf su kalitesine sahiptir (Tablo 1). $\mathrm{NH}_{4}-\mathrm{N}$ değerleri özellikle balıklarda yüksek toksik etki yaptığı için su ürünleri yetiştiriciliğinde önemle takip edilen bir azot formudur. Çözünmüş reaktif azot formları $\left(\mathrm{NH}_{4}-\mathrm{N}, \mathrm{NO}_{2}-\mathrm{N}, \mathrm{NO}_{3}-\mathrm{N}\right)$, TN, TP ve $\mathrm{PO}_{4}-\mathrm{P}$ 'nin su kaynaklarında yüksek seviyelerde bulunması özellikle bu akarsu havzalarında tarım faaliyetlerinin yüksek olması ve ötrofikasyon ile ilişkilendirilmektedir (Dodds vd., 1998). Özellikle azotlu ve fosfatlı gübrelerin tarımda yaygın olarak kullanılması bu besin tuzlarının su kaynaklarında yüksek seviyelere çıkmasına ve ötrofikasyona neden olmaktadır. ABA/AFA'da TN ve $\mathrm{PO}_{4}-\mathrm{P}$ sirasıyla II. ve III. faktörde 
faktör yükü oluşturmuş ve Mustafakemalpaşa Çayı'nda tarımsal faaliyetlerin de önemli bir kirlilik yükü oluşturduğunu işaret etmiştir.

Yapılan değerlendirmeler sonucunda akarsuda özellikle yüksek bor ve arsenik kirliliğinin olduğu, bunun yanında bazı ağır metallerin sınır değerler üzerinde bulunmasının da havzada yapılan madencilik faaliyetleri ile ilişkili olduğu belirlenmiştir. İlerleyen dönemlerde ciddi tedbirler alınmazsa Mustafakemalpaşa Çayı'nın sulama suyu olarak kullanılmasının toprağa ve bitkilere önemli zararlar vereceği ve akarsuyun beslediği ülkemizin en önemli sulak alanlarından biri olan Uluabat Gölü'nün su kalitesinin de Mustafakemalpaşa Çayı tarafından olumsuz etkileneceği sonucuna varılmıştır.

\section{KAYNAKLAR}

AATTUT, (2010). Atıksu arıtma tesisleri teknik usuller tebliği. Çevre ve Orman Bakanlığı. Resmi Gazete, Tarih 20.03.2010, Say1 27527.

Anonim, (1982). Apolyont Gölü ve yan kolları projesi kirlilik gözlem çalışmaları. Devlet Su İşleri Genel Müdürlüğü, I. Bölge Müdürlüğü. 55s.

Anonim, (2001). Madencilik özel ihtisas komisyonu raporu-Metal madenler alt komisyonu krom çalışma grubu raporu. Devlet Planlama Teşkilatı. DPT: 2626 - ÖİK: 637, Ankara

Anonim, (2016). Mustafakemalpaşa sulama birliği denetim raporu. T.C. Bursa Valiliği sulama birlikleri denetim komisyonu. 13s.

Anonim, (2019). ETI Maden. (Erişim tarihi 01/07/ 2019). http://www.etimaden.gov.tr/emet.

APHA, (1998). Standard methods for the examination of water and wastewater (20th ed.). Washington, DC: American Public Health Association.

Arık, F. (2012). Genetic characteristics of the Gozecukuru As-Sb deposits near Kütahya, Turkey. Journal of the Geological Society of India, 80 (6), 855-868. https://doi.org/10.1007/s12594-012-0214-9

Arık, F., \& Yaldı, T. (2010). Heavy metal determination and pollution of the soil and plants of southeast Tavşanlı (Kütahya, Turkey). Clean-Soil, Air, Water, 38 (11), 1017-1030. https://doi.org/10.1002/clen.201000131

Arslan, N., Koç, B., \& Çiçek, A. (2010). Metal contents in water, sediment, and Oligochaeta-Chironomidae of Lake Uluabat, a Ramsar site of Turkey. The Scientific World Journal, 10, 1269-1281. DOI: 10.1100/tsw.2010.117.

Arslan, Ş., \& Çelik, M. (2015). Assessment of the pollutants in soils and surface waters around Gümüşköy silver mine (Kütahya, Turkey). Bulletin of Environmental Contamination and Toxicology, 95 (4), 499-506. https://doi.org/10.1007/s00128-015-1613-6

Bartlett, M.S. (1950). Tests of significance in factor analysis. British Journal of Psychology, 3(2), 77-85. https://doi.org/10.1111/j.2044-8317.1950.tb00285.x

Benzer, S. (2017). Concentrations of arsenic and boron in water, sediment and the tissues of fish in Emet stream (Turkey). Bulletin of Environmental Contamination and Toxicology, 98 (6), 805-810. DOI 10.1007/s00128-016-1996-Z,

BUSKİ, (2019). Kalite izleme. (Erişim tarihi: 20/07/2019). http://www.buski.gov.tr/tr/kaliteizleme/

Cattell, R. B. (1966). The scree test for the number of factors. Multivariate Behavioral Research. 1 (2), 245-276. https://doi.org/10.1207/s15327906mbr0102_10

Cerny, B. A., \& Kaiser, H. F. (1977). A study of a measure of sampling adequacy for factor-analytic correlation matrices. Multivariate Behavioral Research, 12(1), 43-47. https://doi.org/10.1207/s15327906mbr1201_3

Çolak, M., Gemici, Ü., \& Tarcan, G. (2003). The effects of colemanite deposits on the arsenic concentrations of soil and ground water in Igdeköy-Emet, Kütahya, Turkey. Water, Air, and Soil Pollution, 149 (1-4), $127-$ 143. https://doi.org/10.1023/A:1025642331692

Çöl, M., Çöl, C., Soran, A., Sayli, B. S., \& Oztürk, S. (1999). Arsenic-related Bowen's disease, palmar keratosis, and skin cancer. Environmental Health Perspectives, 107 (8), 687-689. DOI: 10.1289/ehp.107-1566498

Çöl, M., \& Çöl, C. (2003). Environmental boron contamination in waters of Hisarcik area in the Kütahya province of Turkey. Food and chemical toxicology, 41 (10), 1417-1420. https://doi.org/10.1016/S02786915(03)00160-1

Çöl, M., \& Çöl, C. (2004). Arsenic concentrations in the surface, well, and drinking waters of the Hisarcik, Turkey, area. Human and Ecological Risk Assessment, 10 (2), 461-465. DOI: $10.1080 / 10807030490438535$

Dalkıran, N. (2006). Orhaneli Çayı'nın epilitik diyatomeleri ile bentik omurgasızlarının ilişkilendirilmesi yoluyla kirlilik düzeyinin saptanması. Uludağ Üniversitesi Fen Bilimleri Enstitüsü, Doktora Tezi, Bursa. 
Dodds, W. K., Jones, J. R., \& Welch, E. B. (1998). Suggested classification of stream trophic state: distributions of temperate stream types by chlorophyll, total nitrogen, and phosphorus. Water Research, 32 (5), 14551462. https://doi.org/10.1016/S0043-1354(97)00370-9

Dogan, M., Dogan, A. U., Celebi, C., \& Baris, Y. I. (2005). Geogenic arsenic and a survey of skin lesions in the Emet region of Kütahya, Turkey. Indoor and Built Environment, 14 (6), 533-536. https://doi.org/10.1177/1420326X05060121

Dziuban, C. D., \& Shirkey, E. C. (1974). When is a correlation matrix appropriate for factor analysis? Some decision rules. Psychological Bulletin, 81 (6), 358. http://dx.doi.org/10.1037/h0036316

Eaton, F. M. (1950). Significance of carbonates in irrigation waters. Soil Science, 69 (2), 123-134.

Elmaci, A., Teksoy, A., Topac, F. O., \& Özengin, N. (2007). Assessment of heavy metals in Lake Uluabat, Turkey. African Journal of Biotechnology, 6(19). http://dx.doi.org/10.5897/AJB2007.000-2351

Erdoğan, Y., Olgun A., Özmal, F., \& Zeybek, B. (2004). Utilization of boron industry wastes, fly ash, bottom ash and alunite mineral in cement production as an additive material. II. Uluslararası Bor Sempozyumu, 23-25 Eylül 2004 Eskişehir, Türkiye.

Field, A. (2013). Discovering statistics using IBM SPSS statistics. SAGE Publications. 4th Edition.

Helvac1, C. (1984). Occurrence of rare borate minerals: Veatchite-A, tunellite, teruggite and cahnite in the Emet borate deposits, Turkey. Mineralium Deposita, 19 (3), 217-226. https://doi.org/10.1007/BF00199788

Helvacı, C. (2003). Türkiye borat yatakları jeolojik konumu, ekonomik önemi ve bor politikası. Balıkesir Üniversitesi Fen Bilimleri Enstitüsü Dergisi, 5 (1), 4-41.

Helvac1, C., \& Alonso, R. N. (2000). Borate deposits of Turkey and Argentina; A Summary and geological comparison. Turkish Journal of Earth Sciences, 9, 1 - 27.

Helvacı, C. (2015a). Bor mineral ve kimyası yönünden genel değerlendirilmesi ve yataklarının gelecek öngörüsü. Madencilik ve Yerbilimleri Dergisi, 47, 66-78.

Helvac1, C. (2015b). Geological features of neogene basins hosting borate deposits: An overview of deposits and future forecast, Turkey. Maden Tetkik ve Arama Dergisi, 151, 169-215. DOI: 10.19111/bmre.05207

Helvac1, C., Stamatakis, M., G., Zagouroglou, C., \& Kanaris, J. (1993). Borate minerals and related authigenic silicates in northeastern Mediterranean late miocene continental basins. Exploration and Mining Geology, 2, 171-178. https://doi.org/10.19111/bmre.71777

Hopkins, B. G., Horneck, D. A., Stevens, R. G., Ellsworth, J. W., \& Sullivan, D. M. (2007). Managing irrigation water quality for crop production in the pacific northwest. A Pacific Northwest Extension publication, (Erişim tarihi 16/07/2019). https://catalog.extension.oregonstate.edu/pnw597

HSKY, 2016. Hassas su kütleleri ile bu kütleleri etkileyen alanların belirlenmesi ve su kalitesinin iyileştirilmesi hakkında yönetmelik. Resmi Gazete, 23 Aralık 2016, Sayı : 29927.

Kaiser, H.F. (1970). A second generation little jiffy. Psychometrika, 35 (4), 401-415. https://doi.org/10.1007/BF02291817

Kaiser, H.F. (1974). An index of factorial simplicity. Psychometrika, 39, 31-36. https://doi.org/10.1007/BF02291575

Kaiser, H. F., \& Rice, J. (1974). Little jiffy, mark IV. Educational and Psychological Measurement, 34 (1), 111 117. http://dx.doi.org/10.1177/001316447403400115

Karacaoğlu, D. (2006). Emet Çayı'nın epipelik diyatomeleri ile bentik omurgasızlarının ilişkilendirilmesi yoluyla kirlilik düzeyinin saptanmast. Uludağ Üniversitesi Fen Bilimleri Enstitüsü. Doktora Tezi. Bursa.

Köse, E., Tokatli, C., \& Çiçek, A. (2014). Monitoring stream water quality: A statistical evaluation. Polish Journal of Environmental Studies, 23 (5). https://doi.org/10.17482/uujfe.39645

Liu, C.W., Lin, K.H. \& Kuo, Y.M. (2003). Application of factor analysis in the assessment of groundwater quality in a blackfoot disease area in Taiwan. Science of the Total Environment, 313 (3), 77-89. https://doi.org/10.1016/S0048-9697(02)00683-6

MTA, (2010a). Kütahya ili maden ve enerji kaynakları. (Erişim tarihi 16/07/2019). http://www.mta.gov.tr/v3.0/sayfalar/bilgimerkezi/maden_potansiyel_2010/kutahya_madenler.pdf.

MTA, (2010b). Bursa ili maden ve enerji kaynakları (Erişim tarihi: 20/07/2019) http://www.mta.gov.tr/v3.0/sayfalar/bilgimerkezi/maden_potansiyel_2010/Bursa_Madenler.pdf

Omwene, P. I., Öncel, M. S., Çelen, M., \& Kobya, M. (2019). Influence of arsenic and boron on the water quality index in mining stressed catchments of Emet and Orhaneli streams (Turkey). Environmental Monitoring and Assessment, 191, 199. https://doi.org/10.1007/s10661-019-7337-z

Oygür, V., \& Erler, A. (1999). Jasperoid tipi epitermal cevherleşmeye batı Anadoludan bir örnek: Değirmenciler antimuan cevherleşmesi (Simav, Kütahya) Maden Tetkik ve Arama Dergisi, 121, 97-113,

Özgenç, İ. (1993). Ovacık (Tavşanlı-Kütahya) fluorît yatağının jeolojisi ve oluşumu. Jeoloji Mühendisliği, 43, 514.

Pett, M.A., Lackey, N.R., \& Sullivan, J.J. (2003). Making sense of factor analysis: The use of factor analysis for instrument development in health care research. California: Sage Publications Inc. 
Richards L. A. (1954). Diagnosis and improvement of saline and alkali soils, United States Department of Agriculture, US Salinity Lab Handbook, 60.

Shrestha, S., \& Kazama, F. (2007). Assessment of surface water quality using multivariate statistical techniques: A case study of the Fuji river basin, Japan. Environmental Modelling and Software, 22, 464-475. https://doi.org/10.1016/j.envsoft.2006.02.001

Semiz, G. D. (2014) Sulama suyu açısından bor içeriğinin değerlendirilmesi: Uluabat Gölünü besleyen Orhaneli, Emet ve Mustafakemalpaşa Çayları. Tekirdağ Ziraat Fakültesi Dergisi, 11 (1), 98-105.

SÜY, (1995). Su ürünleri yönetmeliği. Resmi Gazete, Tarihi:10.03.1995, Sayı: 22223.

Şener, Ş., \& Karakuş, M. (2017). Investigating water quality and arsenic contamination in drinking water resources in the Tavşanlı District (Kütahya, Western Turkey). Environmental Earth Sciences, 76 (21), 750. DOI: $10.1007 / \mathrm{s} 12665-017-7101-\mathrm{z}$

Şimşek, G., Çanlı, M., Karadavut, U., Yazıcı, M. E., \& Soğancı, K. (2017). Sulama yapılan alanların bazı su parametreleri açısından ayırma (discriminant) analizi kullanılarak incelenmesi. Türk Tarım ve Doğa Bilimleri Dergisi, 4 (3), 339-346.

Tokatli, C., Arslan, N., Çiçek, A., Kose, E., Emiroglu, O., \& Dayioglu, H. (2013). Effect of silver on aquatic ecosystems of Emet Stream basin, Turkey. Pakistan Journal of Zoology, 45(2). https://doi.org/10.17482/uujfe.39645

Tokatli, C., Çiçek, A., Emiroğlu, Ö., Arslan, N., Köse, E., \& Dayioğlu, H. (2014). Statistical approaches to evaluate the aquatic ecosystem qualities of a significant mining area: Emet Stream Basin (Turkey). Environmental Earth Sciences, 71 (5), 2185-2197. DOI: 10.1007/s12665-013-2624-4

Tokatlı, C., Köse, E., Arslan, N., Emiroğlu, Ö., Çiçek, A., \& Dayığlu, H. (2016). Ecosystem quality assessment of an aquatic habitat in a globally important boron reserve: Emet Stream Basin (Turkey). International Journal of Environment and Pollution, 59 (2-4), 116-141. DOI: 10.1504/IJEP.2016.079896

TSE, (2005). Türk Standardı TS-266 Sular-insani tüketim amaçlı sular. ICS 13.060.20. Türk Standartları Enstitüsü, Ankara.

Uysal, E., Şen, O. F., Kılıç, Ö. B. D., Candan, N., Uzun, N., Üner, K., Albayrak, B., Bıyıklı, M., Gülşah Üğlü, G., \& Rahmanoğlu, N. (2017). Determination of soil plant available boron and boron nutritional status of tomato plants in major industrial tomato cultivated areas of Turkey. Bor Dergisi, 2 (3), 161-167.

Varol, M., Gökot, B., Bekleyen, A., \& Şen, B. (2012). Water quality assessment and apportionment of pollution sources of Tigris River (Turkey) using multivariate statistical techniques - a case study. River Research and Applications, 28 (9), 1428-1438. https://doi.org/10.1002/rra.1533

Varol, M., Gökot, B., \& Bekleyen, A. (2013). Dissolved heavy metals in the Tigris River (Turkey): spatial and temporal variations. Environmental Science and Pollution Research, 20 (9), 6096-6108. DOI: $10.1007 / \mathrm{s} 11356-013-1627-8$

Wilcox, L. V. (1955). Classification and use of irrigation water. US Department of Agriculture, Circular 969, Washington DC.

YSKY, (2012). Yerüstü su kalitesi yönetmeliği. Resmi Gazete, Tarihi: 30.11.2012, Sayı: 28483. 